\title{
TRANSFORMATION OF THE ZAGREB URBAN REGION
}

\author{
Milan Ilić*, Aleksandar Toskić** \\ Geografski odsjek, Marulićev trg 19, 10000 Zagreb \\ *e-mail: milic@geog.pmf.hr \\ *e-mail: atoskic@geog.pmf.hr
}

\begin{abstract}
Several aspects of the transformation of the Zagreb urban region are considered in this work: change in the region's size and form, socio-economic transformation, functional transformation and physiognomic or morphological transformation. It was established that the region's form has changed: it is moving from the classic star-like form, characteristic of the early developmental phase of the urban region, to a circular form. The region has experienced evolution in the developmental sense and reached a phase of absolute decentralization. The process of transformation in the region is continuing at full pace, while only peripheral, mainly small and poorly linked settlements with an unfavorable demographic balance and processes are lagging behind.
\end{abstract}

Key words: Zagreb Urban region, socio-economic transformation, functional transformation, physiognomic transformation

\section{TRANSFORMACIJA ZAGREBŠKE URBANE REGIJE}

Trasformacija mestne regije Zagreba je prikazana $\mathrm{z}$ različnih vidikov: spremembe velikosti in oblike regije, socio-ekonomske, funkcionalne ter fiziognomske ali morfološke preobrazbe. Ugotovljena je spremenjena oblika regije od klasične zvezdaste, ki je bila značilna za zgodnje obdobje mestnega razvoja, do krožne. Ob tem pa so na vzhodnem delu še vidne močnejše usmeritve v zone prometnih koridorjev. Regija je doživela preobrazbo tudi v razvojnem pogledu in je dosegla fazo absolutne decentralizacije.

Ključne besede: Zagrebška urbana regija, socio-ekonomska, funkcionalna in fiziognomska preobrazba 


\section{INTRODUCTION}

A city and its surroundings form a functional whole characterized by constant and intense interaction. Since the term "surroundings" is relatively unspecific, the need arose to clearly define and isolate areas which have the most intense links to the city and in which the results of these links are best observed. This area, together with the central city, form the urban region. The criteria for discerning them can differ: demographic trends, daily commutes and other functional links, distance, etc.

Several aspects of the transformation of the Zagreb urban region are considered in this work: change in the region's size and form, socio-economic transformation, functional transformation and physiognomic or morphological transformation.

\section{SIZE AND FORM OF THE REGION}

The change in the size and form of the Zagreb urban region is analyzed by reviewing and comparing earlier research into this problem. This topic first began to appear in geographic scholarship at the beginning of the 1960s, after the city's surroundings experienced intense transformation. This was prompted by Zagreb's drastic growth, and the enhancement of its labor functions due to intense industrial development. This in turn led to growth in daily commutes from the city's surrounding area, which was reflected in changes in the socioeconomic characteristics of the population of this area and the gradual penetration of urban lifestyles into settlements located here. Although the relationship between the city and its environs were conducted even earlier, the first systematic definition of the Zagreb urban region was made by Žuljić $(1964,1965)$, using data from the 1961 census.

Žuljić defines the urban region, or the "Zagreb metropolitan region" as he calls it, as that portion of the environs which is functionally linked to Zagreb and forms a consolidated regional urban complex. Daily commutes by the labor force are used to measure this functional link. Based on the share of the agricultural population, the marked tendency toward physiognomic transformation, and the migration balance, Žuljić discerned narrower and broader urbanization zones within the urban region.

Defined as such, the Zagreb urban region encompassed 155 settlements. It had a very star-like form that extends along the main transit routes. Such a form is characteristic of the early phase of development in an urban region, wherein the dominant role is played by rail traffic as the principal means of travel to and from the central city.

A new definition of the urban region emerged after the 1971 census (Vresk, 1978). The Zagreb urban region (socio-economic region) was defined on the basis of two groups of indicators, or more precisely, four variables. The degree of socio-economic transformation of settlements is determined on the basis of the agricultural population as a share of the total and the share of employed in the active population. The link with Zagreb is also significant; this depends on whether Zagreb or one of its satellites is the primary center of labor for an individual settlement, which must also be a part of the contiguous environs. 
Based on these criteria, an urban region was distinguished which encompasses 244 settlements. Among them, besides 11 settlements statistically defined as urban, 105 settlements were discerned which are more urbanized (experienced a higher degree of socio-economic transformation) and 128 less urbanized settlements.

The urban region still had a very star-like form, with narrow urbanized belts that extended along the main transit links with satellite centers. This was particularly apparent in the southern and eastern section of the region, while in the west and northwest the urbanized belt was wider.

After the next subsequent census, another new model for defining the Zagreb urban region was developed (Vresk, 1984), which added a new criterion in addition to the aforementioned criteria. This was the share of households with agricultural property as an indicator of lifestyle change in individual settlements. Over and above this, the criteria for the remaining indicators became more rigorous. This resulted in a reduction of the extent of the region called the "Zagreb metropolitan region." It encompasses 138 settlements, of which 9 are urban, 59 more urbanized and 71 less urbanized. The region's total population (according to these new dimensions) over the last intercensal period increased $20 \%$, which is considerably higher than the growth of Croatia's overall population. Even more importantly, changes occurred in the region's developmental trends: for the first time the population in the environs grew faster than the population in the central city. Satellite settlements in particular grew very quickly. There were also certain, albeit modest, changes in the region's form. Although the ray-like extension along major transit routes was still marked, there was a gradually "filling in" of the space between them. This resulted from more intense road traffic, which covered the otherwise dispersed areas. The key role here was played by public urban bus transportation, with an increasingly developed network that encompassed more of the environs. The growing availability and use of automobiles were also very important.

After the 1991 census, the Zagreb urban region was once more redefined (Vresk, 1997). The basic change this time was that delineation was carried out at the level of the new municipalities rather than at the settlement level. The definition of the urban region was based on two criteria: the share of employed in the active population and the share of daily commuters to and from Zagreb. The region thus defined encompasses the City of Zagreb and 15 surrounding municipalities. There were also some changes to the region's form: the urban region now almost continually encircles the central city (except in the northeast, which can be interpreted as a relief barrier to stronger links). Most municipalities have a higher degree of socio-economic transformation, which becomes less intense as the distance from the central city becomes greater. It should be noted that the weaker links between Samobor and Dugo Selo and Zagreb follows from the fact that both of these are also strong labor centers, thus reducing the need for commuting to Zagreb. In the demographic sense, the environs grew much faster than the central city (1991/81 index for the central city is 106, and 119 for the environs) (Bašić, 2003).

All of the relevant data from the 2001 census that would facilitate the definition of the Zagreb urban region in comparison to preceding definitions or to devise a redefined model are still not available. So in this work, the spatial extent defined using the 1991 indi- 
cators is taken to analyze the transformation of the Zagreb urban region after 1991. However, due to changes in census methodology, the results from the 2001 census cannot be compared with previous censuses with complete accuracy (Bašić, 2003). This pertains to the higher population and, consequently, on structures.

In the last intercensal period, the population of the Zagreb urban region grew $2.3 \%$. However, it is more important to stress another turning point in the region's development, and that is the commencement of a phase of absolute decentralization (Bašić, 2003). This means that the population of the central city declined (index 97.6), while that of the environs rose (index 115.8).

\section{SOCIO-ECONOMIC TRANSFORMATION}

Socio-economic transformation implies changes in the status of a population in the social hierarchy. In rural settlements, this most often means employment of the population in nonagricultural occupations and the associated lifestyle change (Vresk, 1997). Since there are, as a rule, few workplaces in a village, this transformation is facilitated by daily commuting of employed persons to labor centers, usually the central city. Based on the share of the agricultural in the overall population and the share of employed persons in the active population, the degree of socio-economic transformation of settlements in the Zagreb urban region was determined. Out of the total 342 settlements (not including Zagreb), 5 are urban: Dugo Selo, Samobor, Sesvete, Velika Gorica and Zaprešić. Based on these criteria, more and less urbanized and rural settlements were discerned (Vresk, 1997; Bašić, 2003) (Table 1)

Table 1: Settlements in the Zagreb urban region (not including Zagreb) based on degree of urbanization and size in 1991

\begin{tabular}{|l|r|r|}
\hline type & number & average size \\
\hline urban & 5 & 20661 \\
\hline more urbanized & 155 & 605 \\
\hline less urbanized & 83 & 350 \\
\hline rural & 98 & 231 \\
\hline
\end{tabular}

Source: Population census of 1991 - data specifically processed for the needs of the research project entitled 'Urbanization of Croatia,' National Statistics Bureau, Zagreb.

From Table 1 and Figure 1 it is apparent that more urbanized settlements are the largest in number. They account for an almost contiguous and relatively broad zone in the western section of the region, while in the eastern section urbanization axes along primary transit corridors are still visible (Vresk, 1993). This indicates a chronologically unequal course of urbanization. Settlements that experienced a lesser degree of transformation are adjacent to these, while rural settlements are located in peripheral, more isolated areas and in zones between the major transit corridors. There is also a visible correlation between the size of settlements and the degree of transformation: larger settlements are more urbanized than smaller ones. 
Figure 1: Levels of urbanization according to settlements of the Zagreb urban region 1991 (1-urban, 2-more urbanized, 3-less urbanized, 4-rural settlements, 5-railway, 6-motorway, 7-freeway, 8-state road, 9-county road)

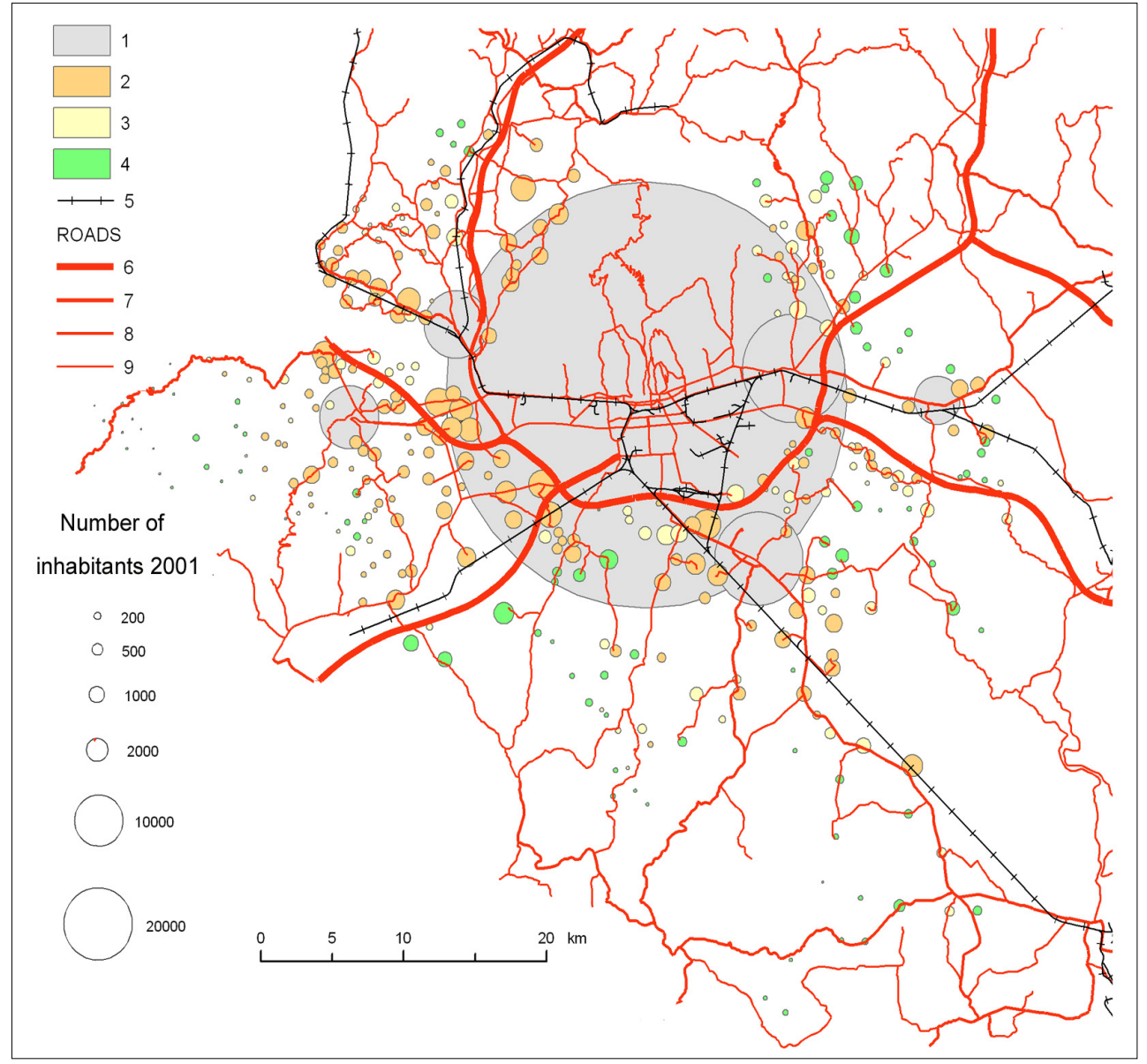

Socio-economic transformation processes during the last intercensal period can only be analyzed partially due to the lack of relevant data.

A comparison of the share of the agricultural population in the overall active population in 1991 and 2001 shows that this share declined over this period in 287 (84\%) settlements in the Zagreb urban region. Settlements in zones adjacent to transit routes (Fig. 2a and $2 b$ ) in particular experienced a decline in the share of the agricultural population. Only 53 settlements, mostly smaller (38 have less than 500 residents, while 29 have less than 200) recorded growth in the share of the agricultural population. 
Figure 2a: The share of the agricultural population according to settlements of the Zagreb urban region 1991(1-railway, 2-motorway, 3-freeway, 4-state road, 5-county road)

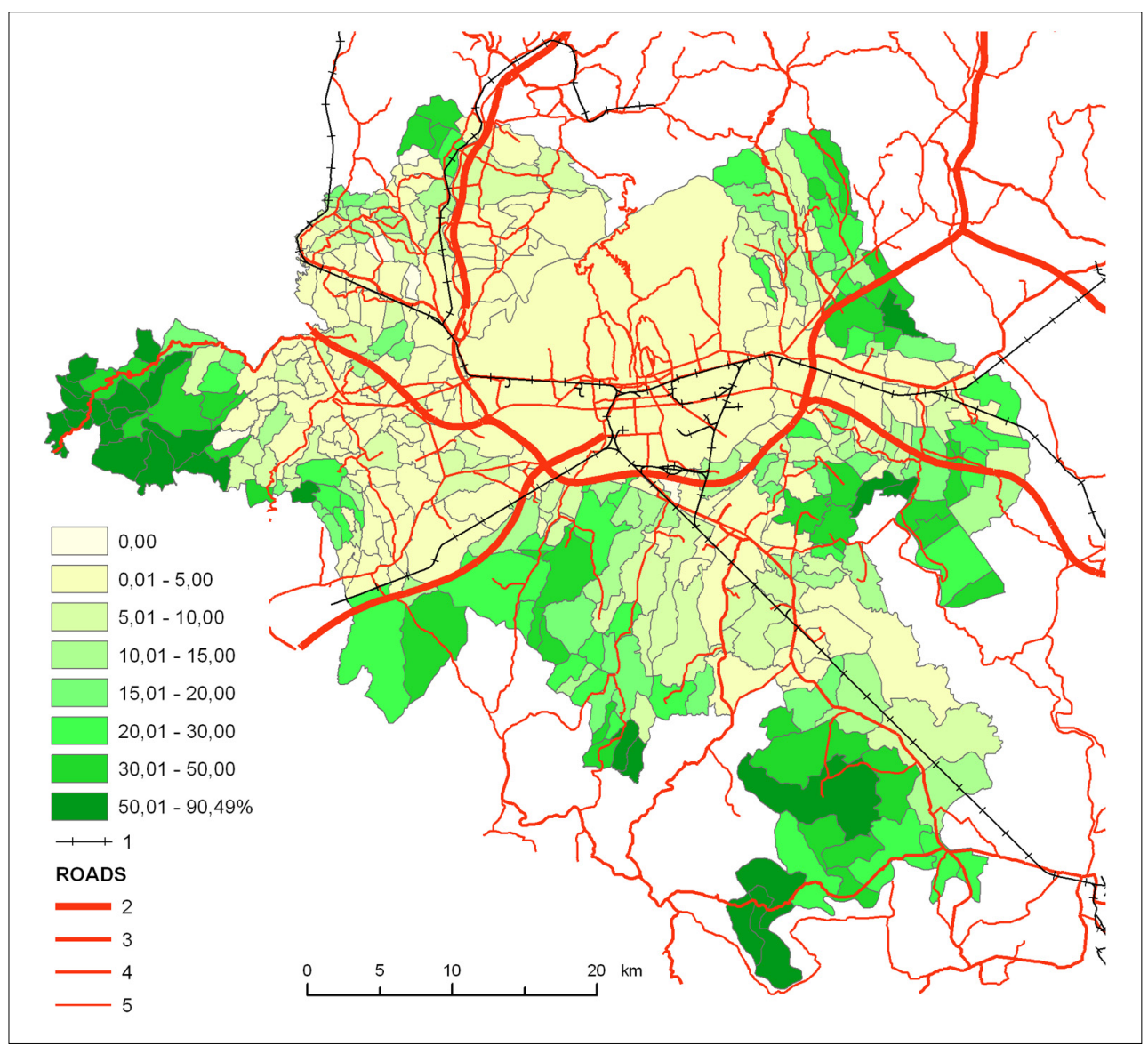

The other indicator of socio-economic transformation is the share of daily commuters. As stated, daily commuting to work is one of the principal agents of transformation in settlements, so that the intensity of daily commuting and the degree of transformation in a settlement largely overlap. The zones of most intense commuting, as can be expected, encircle the larger centers of labor and extend along the major thoroughfares (Fig. 3). Settlements in the region's periphery (generally small) have a smaller share of daily commuters, as do those located between major transit corridors and, of course, urban settlements that are themselves important labor centers. Out of the total number of settlements, less than a third (96) have a share of $50 \%$ or less of daily commuters among their employed. Out of the remaining number, 107 of the settlements have a $50-60 \%$ share of commuters, while 110 settlements have a $60-70 \%$ share of commuters among the employed. 28 settlements have a share of commuters that surpasses $70 \%$. 
Figure 2b: The share of the agricultural population according to settlements of the Zagreb urban region 2001 (1-railway, 2-motorway, 3-freeway, 4-state road, 5-county road)

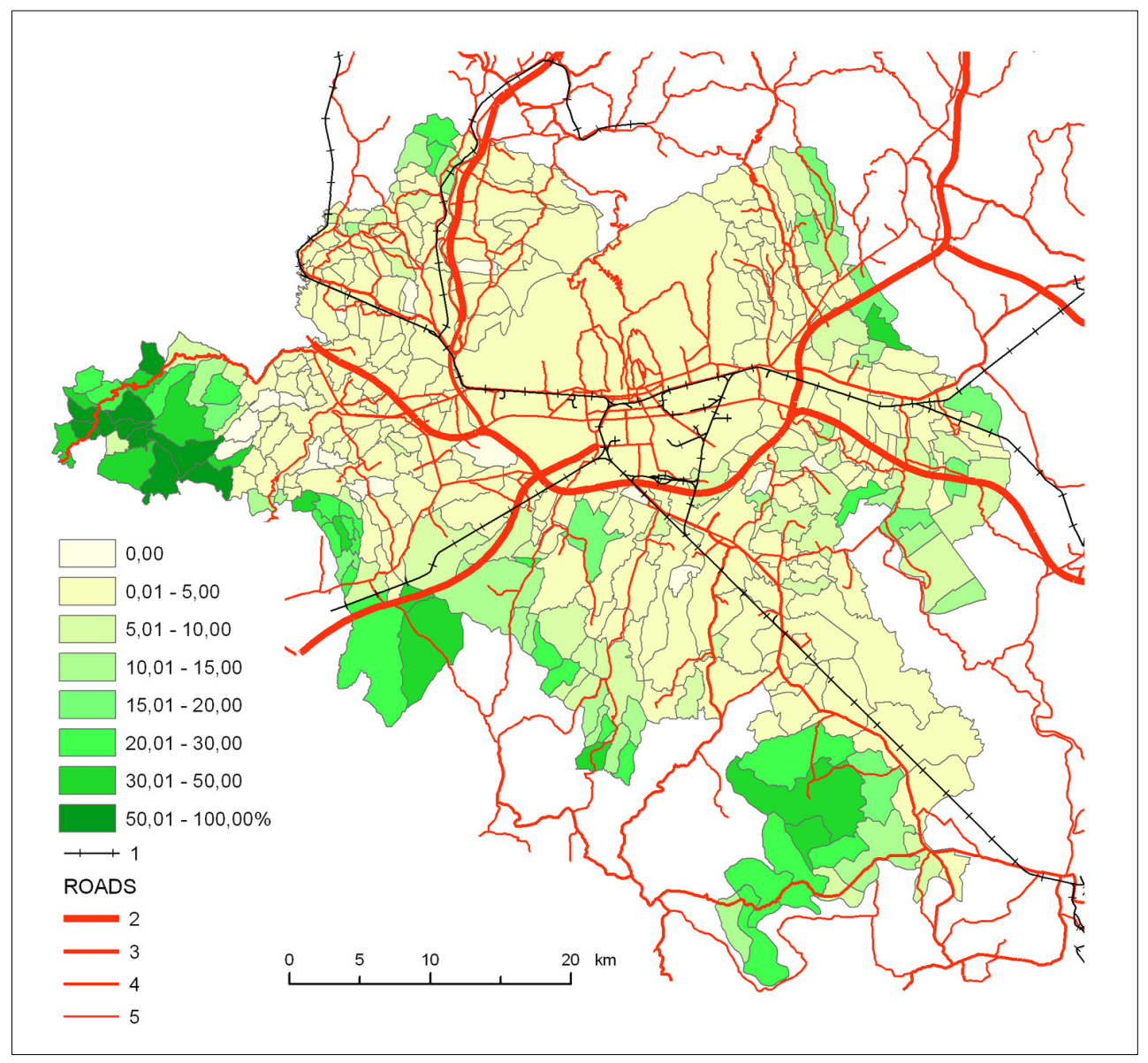

\section{FUNCTIONAL TRANSFORMATION}

Functional transformation is viewed through the prism of labor functions, to the extent that the relevant data is available. In 1991, approximately 368,800 workplaces were recorded in the Zagreb urban region. Out of this, approximately $90 \%$ were in the central city, while only $10 \%$ were in the environs. Although the processes of decentralization of industry and its physical expansion toward the suburban zone and the wider urban region had already commenced during the 1960 s, one could still speak of the intensely centralized labor function. Furthermore, among the workplaces in the environs, two thirds were in satellite settlements ( 5 of them), which is a result of the fact that under the previous administrative organization they were municipal seats (Toskić, 1998). Therefore, one can speak of a concentration of workplaces at the local level. Out of the remaining settlements, one more 
(Kerestinec) has approximately 1,000 employed persons, while all others lag behind considerably.

Figure 3: The share of the daily commuters according to settlements of the Zagreb urban region 2001 (1-railway, 2-motorway, 3-freeway, 4-state road, 5-county road)

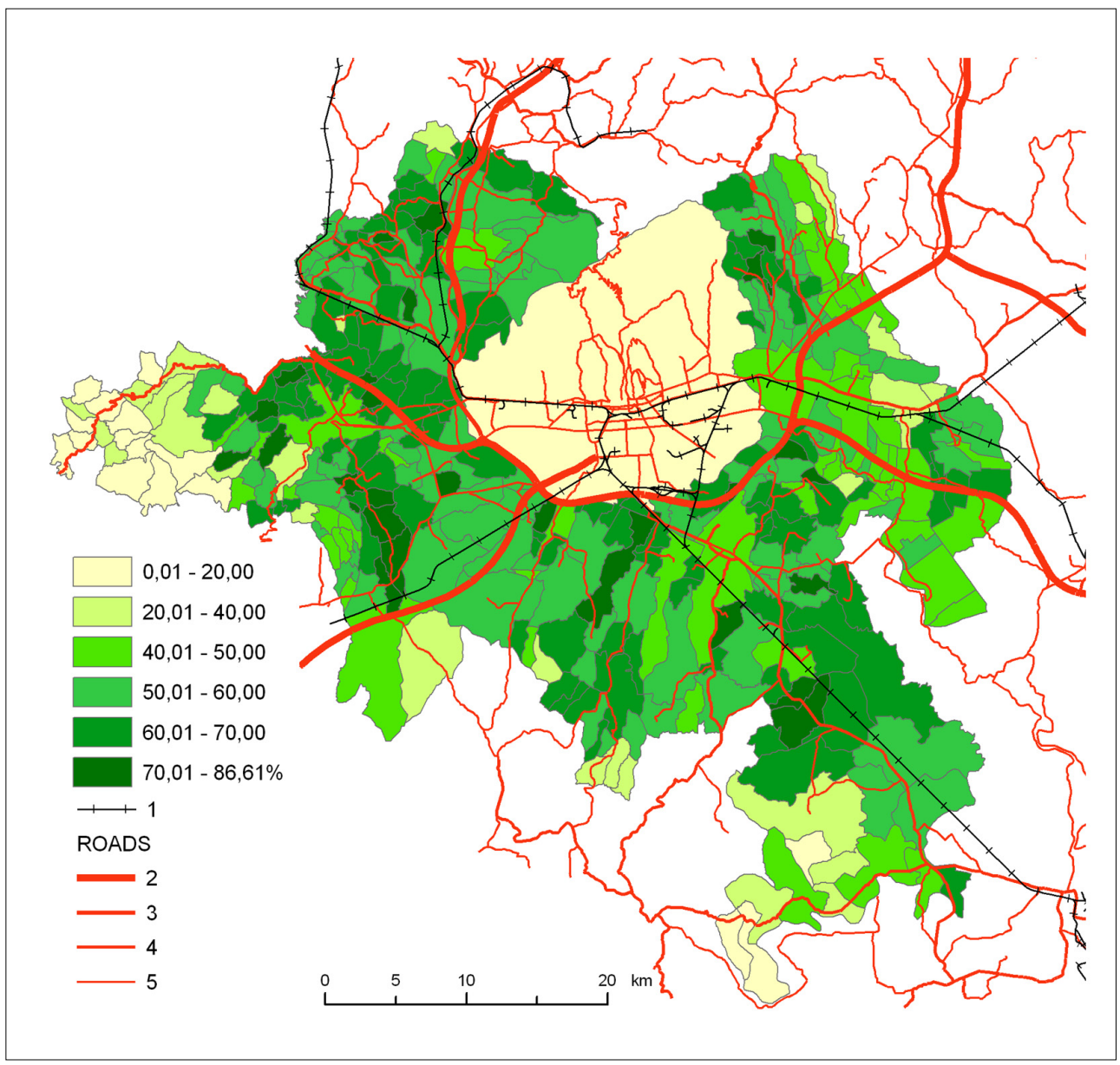

Changes over the last decade cannot be considered for this indicator because new data on jobs are not available. Change in the number of businesses in individual settlements will be used as an indirect indicator. Transition processes were clearly the principal reason for the establishment of numerous companies during the 1990s. Nevertheless, since such processes were equally present in all areas, they can indirectly indicate specific changes in the labor function, meaning changes in the functional orientation of settlements, the appearance of non-agricultural activities and free enterprise in general. 
Table 2: Businesses in the Zagreb urban region in 1991 and 2000

\begin{tabular}{|l|r|r|r|r|r|}
\hline \multirow{2}{*}{ Section of region } & \multicolumn{2}{|c|}{ Number } & \multicolumn{2}{c|}{ Share (\%) } & \multicolumn{1}{c|}{ Index } \\
\cline { 2 - 5 } & 1991 & 2000 & 1991 & 2000 & $2000 / 1999$ \\
\hline Zagreb & 10119 & 55733 & 82,3 & 82,7 & 550,8 \\
\hline Satellite cities & 1336 & 7106 & 10,9 & 10,5 & 531,9 \\
\hline Other settlement & 844 & 4571 & 6,9 & 6,8 & 541,6 \\
\hline Total & 12299 & 67410 & 100 & 100 & 548,1 \\
\hline
\end{tabular}

Source: Businesses by settlements in Croatia in 1991 and 2000, specially processed tables of the National Statistics Bureau, Zagreb.

The data in Table 2 confirm empirical knowledge on the intense expansion of business activities during the period under observation: the number of businesses in the Zagreb urban region increased by a factor of 5.5. Less expected is that the differences between individual components are relatively small. Although Zagreb has the highest index of changewhich could have been assumed and which indicates the further concentration of business activities - it is only slightly higher than the average for the region. More important are the differences in the environs: growth in the number of businesses in satellite settlements was slower than in other settlements. This is partially due to the fact that these settlements were already strong labor centers with numerous smaller firms and sole trades even before, and partially due to what can be called a dispersion of business activity over the entire region, so that at least one company or sole trade was opened in many settlements. So in 1991, one third of the settlements (108) did not have any businesses, while in 200 only 49 settlements, mostly small (population less than 200) settlements in the periphery, had no businesses. The number of settlements with a small number of firms (5 or less) also fell, while the number of those with many businesses, particularly between 25 and 50 businesses, grew, and this can be already be deemed a considerable level of business activity. Settlements with the highest number of businesses and the highest index of change are located along major transit routes (Fig. 4). Additionally, the grouping of such settlements into genuine business zones is apparent, particularly in the western section of the region.

\section{PHYSIOGNOMIC TRANSFORMATION}

Physiognomic or morphological transformation refers to the change in the appearance of settlements as a result of socio-economic and functional transformation. It is, therefore, a reflection of change in the occupation of the population and the associated lifestyle changes. This means that in rural settlements the number of households with auxiliary buildings declines, or such buildings are transformed into workshops, warehouses, etc. as a result of the decline in agricultural activities. Houses and the surrounding yards become increasingly similar to urban houses, with many of them bearing some kind of sign indicating that some form of business activity is conducted there. Elements characteristic of cities begin to appear in settlements: sidewalks and other infrastructure are constructed, special- 
ized shops and public institutions (post office, community health centers, pharmacies) appear, solid waste collection is organized, and so forth. A field survey of the Zagreb urban region confirmed that the process of urbanization is proceeding apace, and that many settlements, when the data becomes available, will show a higher degree of urbanization than in 1991.

Figure 4: Index of changes of businesses in Zagreb urban region 1991-2000

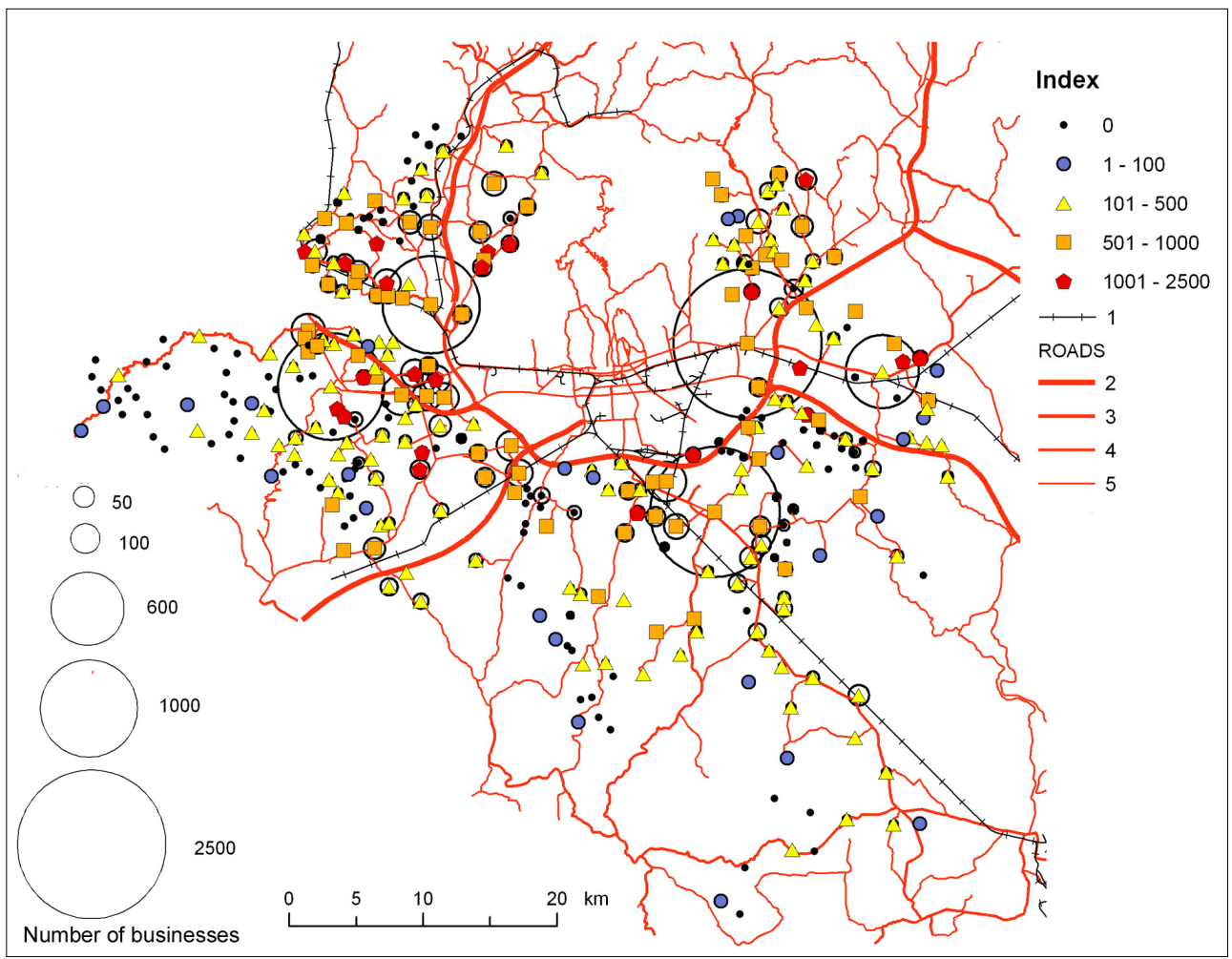

\section{CONCLUSION}

Since the beginning of the 1960s, when research into the Zagreb urban region began, this region has experienced significant and comprehensive changes. These changes primarily pertain to the size and appearance of the region. Despite changes in criteria which determine whether or not a settlement belongs in the urban region, it can nonetheless be asserted that the region under the city's most intense influence and most strongly linked to it has grown. The region's form has changed: it is moving from the classic star-like form, characteristic of the early developmental phase of the urban region, to a circular form, even though zones of greater transformation along transit corridors are still visible in its eastern section. The region has experienced evolution in the developmental sense and reached a 
phase of absolute decentralization, in which the entire region's population is growing, even as the population of the central city is declining. Already in 1991, over two thirds of the settlements exhibited at least some socio-economic transformation, while the majority experienced a high degree of such transformation. Further research should be conducted into studying changes after 1991, particularly in correlation with the development of the system of public urban and suburban transportation as one of the principal means of interaction between the city and its environs. The available data show that the process of transformation in the region is continuing at full pace, while only peripheral, mainly small and poorly linked settlements with an unfavorable demographic balance and processes are lagging behind.

\section{References}

Bašić, K., 2003: Suburbanizacija Zagreba - demogeografski aspekt procesa, PhD thesis, Zagreb.

Toskić, A., 1998: Utjecaj političko-teritorijalne organizacije Hrvatske na lokaciju uslužnih i proizvodnih djelatnosti. Hrvatski geografski glasnik 60, Zagreb, 59-73.

Vresk, M., 1978: Gradska regija Zagreba. Geografski glasnik 40, Zagreb, 59-87.

Vresk, M., 1984: Metropolitanska regija Zagreba 1981. godine. Radovi GO 19, Zagreb, 59-66.

Vresk, M., 1993: Prometne osovine i osovine urbanizacije Središnje Hrvatske. Geografski glasnik 54, Zagreb, 81-88.

Vresk, M, 1997: Suburbanizacija Zagreba. Hrvatski geografski glasnik 59, Zagreb, 49-71.

Žuljić, S., 1964: Zagreb i okolica - utjecaj gradskog organizma na regiju, I dio. Geografski glasnik 24, Zagreb, 65-182.

Žuljić, S., 1965: Zagreb i okolica - utjecaj gradskog organizma na regiju, II dio. Geografski glasnik 25, Zagreb, 39-147. 